\title{
PENGARUH PEMBERIAN SUSU KORO PEDANG (Canavalia ensiformis) TERHADAP KADAR KOLESTEROL TOTAL DAN TRIGLISERIDA SERUM TIKUS SPRAGUE DAWLEY HIPERKOLESTEROLEMIA
}

\author{
Maria Annisa Primawestri, Ninik Rustanti*) \\ Program Studi Ilmu Gizi Fakultas Kedokteran Universitas Diponegoro \\ Jl.Dr.Sutomo No.18, Semarang, Telp (024) 8453708, Email : gizifk@undip.ac.id
}

\begin{abstract}
Background: Elevation of total cholesterol and triglyceride are contribute factors of atherosclerosis onset and cardiovascular disease. Jack bean milk is a natural source of fiber, saponin, isoflavone, niacin, and phenol in food. The aim of this study was to analyze the effects of jack bean milk administration towards total cholesterol and triglyceride serum level in hypercholesterolemic rats.

Methods: True experimental study with pre-post test was conducted to 24 hypercholesterolemic male Sprague dawley rats which grouped into: 1 control group and 3 treatment groups. Various amounts of jack bean milk were administered, as much as $2.25 \mathrm{~g}, 4.5 \mathrm{~g}$, and $9 \mathrm{~g}$. Total cholesterol and triglyceride serum level were determined using CHOD-PAP and GPO-PAP methods. All datas collected were analyzed using paired t-test and One Way ANOVA followed by LSD test at $95 \%$ confidence level.

Results: Jack bean milk administration in various amounts were able to show lowering effect on total cholesterol and triglyceride serum level. Rats given jack bean milk with amount of $9 \mathrm{~g}$ show the biggest lowering effect on total cholesterol serum level as much as $33.54 \%$ and the biggest lowering effect on triglyceride serum level was shown in rats given jack bean milk with amount of $4.5 \mathrm{~g}$ as much as $40.9 \%$. Control group without jack bean milk administration had increased total cholesterol and triglyceride serum level, as much as $6.85 \%$ and $12.1 \%$ respectively.
\end{abstract}

Conclusion: Jack bean milk administration was able to show significant lowering effect to total cholesterol and triglyceride serum level in hypercholesterolemic rats.

Key words: jack bean milk; total cholesterol; triglyceride; hypercholesterolemia

\section{ABSTRAK}

Latar Belakang: Peningkatan kadar kolesterol total dan trigliserida meningkatkan resiko terjadinya aterosklerosis dan penyakit kardiovaskuler. Susu koro pedang merupakan makanan yang mengandung serat, isoflavon, saponin, niasin, dan fenol yang efektif menurunkan kadar kolesterol total dan trigliserida. Penelitian ini bertujuan untuk menganalisis pengaruh pemberian susu koro pedang terhadap kadar kolesterol total dan trigliserida serum tikus hiperkolesterolemia.

Metoda: Penelitian eksperimental dengan pre-post test dilakukan pada 24 tikus Sprague dawley jantan hiperkolesterolemia yang dikelompokkan menjadi 4 kelompok perlakuan yaitu: 1 kelompok kontrol dan 3 kelompok yang diberikan susu dari kacang koro pedang sebanyak $2.25 \mathrm{~g}, 4.5 \mathrm{~g}$, dan $9 \mathrm{~g}$ selama 14 hari. Kadar kolesterol total dan trigliserida serum ditentukan melalui metode CHOD-PAP dan GPO-PAP. Data dianalisis dengan paired $t$-test dan One Way ANOVA yang dilanjutkan dengan uji LSD pada tingkat kepercayaan 95\%.

Hasil: Pemberian susu koro pedang mampu menurunkan kadar kolesterol total dan trigliserida serum. Penurunan kadar kolesterol total serum terbesar terjadi pada tikus yang mendapat susu dengan kadar koro pedang $9 \mathrm{~g}$ (33.54\%) dan penurunan kadar trigliserida serum terbesar terjadi pada tikus yang mendapat susu dengan kadar koro pedang $4.5 \mathrm{~g}$ (40.9\%). Pada kelompok kontrol tanpa pemberian susu koro pedang, kadar kolesterol total dan trigliserida serum mengalami peningkatan, masing-masing sebesar $6.85 \%$ dan $12.1 \%$.

Kesimpulan: Pemberian susu koro pedang dapat menurunkan kadar serum kolesterol total dan trigliserida serum secara signifikan pada tikus hiperkolesterolemia.

Kata kunci : susu koro pedang; kolesterol total; trigliserida; hiperkolesterolemia

\section{PENDAHULUAN}

Hiperkolesterolemia adalah suatu kondisi dimana terjadi kenaikan kadar kolesterol total $\geq 240$ $\mathrm{mg} / \mathrm{dl}$ dan trigliserida $\geq 200 \mathrm{mg} / \mathrm{dl}$. Hiperkolesterolemia merupakan faktor aterogenik yang berperan pada kejadian aterosklerosis (pengerasan dinding pembuluh darah akibat timbunan plak sehingga membatasi atau menghambat aliran darah) dan menjadi salah satu faktor resiko terjadinya penyakit kardiovaskuler. ${ }^{1}$

Organisasi Kesehatan Dunia menyebutkan bahwa prevalensi global kenaikan kadar kolesterol mencapai 39\% dan menjadi penyebab 2.6 juta kematian (4.5\%). Prevalensi kenaikan kolesterol di negara-negara Asia Tenggara mencapai $29 \%$. Selain kenaikan kadar kolesterol total, faktor

\footnotetext{
${ }^{*}$ Penulis Penanggungjawab
} 
resiko penyakit kardiovaskuler lainnya adalah kenaikan kadar trigliserida. Sebuah penelitian meta analisis terhadap ratusan pasien selama 10 tahun menyimpulkan bahwa resiko terkena penyakit kardiovaskuler meningkat sebesar $32 \%$ setiap peningkatan kadar trigliserida sebanyak 1 $\mathrm{mmol} / \mathrm{L}^{\mathbf{1 - 2}}$

Kenaikan kadar kolesterol total dan trigliserida dapat dicegah melalui pola makan. Perubahan pola makan yang dimaksud adalah modifikasi diet. Secara umum diet yang disarankan adalah dengan membatasi konsumsi kolesterol dan lemak serta mengkonsumsi jenis bahan makanan yang dapat menurunkan kolesterol total dan trigliserida seperti kacang koro pedang (Canavalia ensiformis). ${ }^{3}$

Kacang koro pedang mempunyai kandungan gizi yang hampir sama dengan kedelai (Glycine max) sehingga dapat digunakan sebagai pengganti kedelai. Kacang koro pedang mempunyai kandungan karbohidrat $(66.1 \%)$ dan protein yang tinggi $(27.4 \%)$ serta lemak yang lebih rendah $(2.9 \%)$. Selain itu, koro pedang mengandung berbagai zat gizi yang bersifat hipokolesterolemik seperti: niasin, serat, isoflavon, fenol, dan saponin. Kelebihan koro pedang lainnya adalah harga jual yang lebih murah dan mudah dibudidayakan dibandingkan kedelai. Ketersediaan kacang koro pedang di Indonesia, khususnya Provinsi Jawa Tengah cukup baik karena berhasil dibudidayakan di 12 kabupaten dengan hasil \pm 216 ton setiap kali panen dari total luas lahan $24 \mathrm{Ha}^{4-8}$

Sebuah penelitian pada tikus diabetes mellitus dengan induksi Alloxan menunjukkan bahwa ekstrak kacang koro pedang yang dikonsumsi secara oral dapat menurunkan kadar trigliserida sebanyak $58.5 \%$ dan kadar kolesterol total sebanyak $39.6 \%$. Penelitian lain pada tikus ovariektomi yang diberikan bubuk koro pedang sebanyak $50 \mathrm{~g}$ memiliki total kolesterol hepar, plasma kolesterol total, dan plasma trigliserida yang lebih rendah dibandingkan dengan tikus yang diberikan bubuk kedelai. ${ }^{3,9}$

Salah satu olahan kacang koro pedang yang mudah dibuat adalah susu. Pemberian susu koro pedang ditentukan berdasarkan rekomendasi dari FDA (Food and Drug Administration) bahwa asupan kacang kedelai sebanyak 25 g/hari pada manusia dapat menurunkan kolesterol. Selanjutnya kadar tersebut dikonversi menggunakan konversi Paget and Barnes sehingga didapatkan hasil $4.5 \mathrm{~g}$ kacang koro pedang. Kadar lainnya didapat dari setengah kadar konversi dan kelipatan dua kadar konversi, masing-masing sebanyak $2.25 \mathrm{~g}$ dan $9 \mathrm{~g}$ kacang koro pedang. ${ }^{\mathbf{1 0}}$
Subjek penelitian ini menggunakan tikus Sprague dawley jantan karena memiliki karakter fisiologis yang hampir sama dengan manusia, responsif terhadap diet hiperkolesterolemia namun memiliki kestabilan kadar fosfolipid yang baik. Penelitian ini bertujuan untuk menganalisis pengaruh pemberian susu koro pedang pada berbagai kadar terhadap perubahan dan perbedaan kadar kolesterol total dan trigliserida serum tikus Sprague dawley hiperkolesterolemia. ${ }^{11-12}$

\section{METODE \\ Subjek Penelitian}

Subjek yang digunakan pada penelitian ini adalah tikus jantan Sprague dawley berusia 6 minggu dengan berat badan 70-120 gram yang diperoleh dari Bagian Farmakologi dan Farmasi Klinik, Fakultas Farmasi, Universitas Gadjah Mada Yogyakarta. Pemeliharaan hewan coba dilakukan di Laboratorium Fisiologi Hewan Fakultas MIPA, Universitas Negeri Semarang.

\section{Bahan}

Bahan yang digunakan selama penelitian berlangsung meliputi pakan standar, pakan tinggi kolesterol, dan susu koro pedang. Pakan standar yang digunakan adalah jenis BR 2 (Broiler Finisher) Comfeed dengan aquades, sedangkan pakan tinggi kolesterol adalah otak sapi $1.28 \mathrm{~g}$ per tikus. Uji kandungan zat gizi kacang dan susu koro pedang dilakukan di UPT Laboratorium Gizi dan Teknologi Pangan Universitas Muhammadiyah Semarang.

\section{Metode Penelitian}

Penelitian ini menggunakan rancangan true experiment dengan pre-post test. ${ }^{13}$ Pemilihan subjek penelitian untuk pengelompokan dan perlakuan yang diberikan menggunakan sistem acak sederhana. Variabel bebas adalah pemberian susu koro pedang berbagai kadar, sedangkan variabel terikat adalah kadar kolesterol total dan trigliserida serum tikus hiperkolesterolemia. Subjek penelitian dibagi menjadi 4 kelompok dengan keterangan sebagai berikut

$\mathrm{K} \quad$ : Kelompok Kontrol (pakan standar)

P1 : Kelompok Perlakuan 1 (susu koro pedang $2.25 \mathrm{~g}$ sebanyak $3 \mathrm{ml}$ )

P2 : Kelompok Perlakuan 2 (susu koro pedang $4.5 \mathrm{~g}$ sebanyak $3 \mathrm{ml}$ )

P3 : Kelompok Perlakuan 3 (susu koro pedang $9 \mathrm{~g}$ sebanyak $3 \mathrm{ml}$ )

Setiap kelompok memiliki jumlah subjek yang dihitung menggunakan rumus besar subjek eksperimental dari Federer dengan hasil subjek minimal 6 ekor per kelompok. Untuk antisipasi drop out, maka ditambahkan masing-masing 
sejumlah 1 ekor tikus per kelompok sehingga jumlah keseluruhan subjek dalam penelitian ini adalah 28 ekor tikus. ${ }^{13}$

\section{Tahapan Penelitian}

Penelitian dilaksanakan dalam beberapa tahap yang dapat dilihat dalam gambar berikut ini:

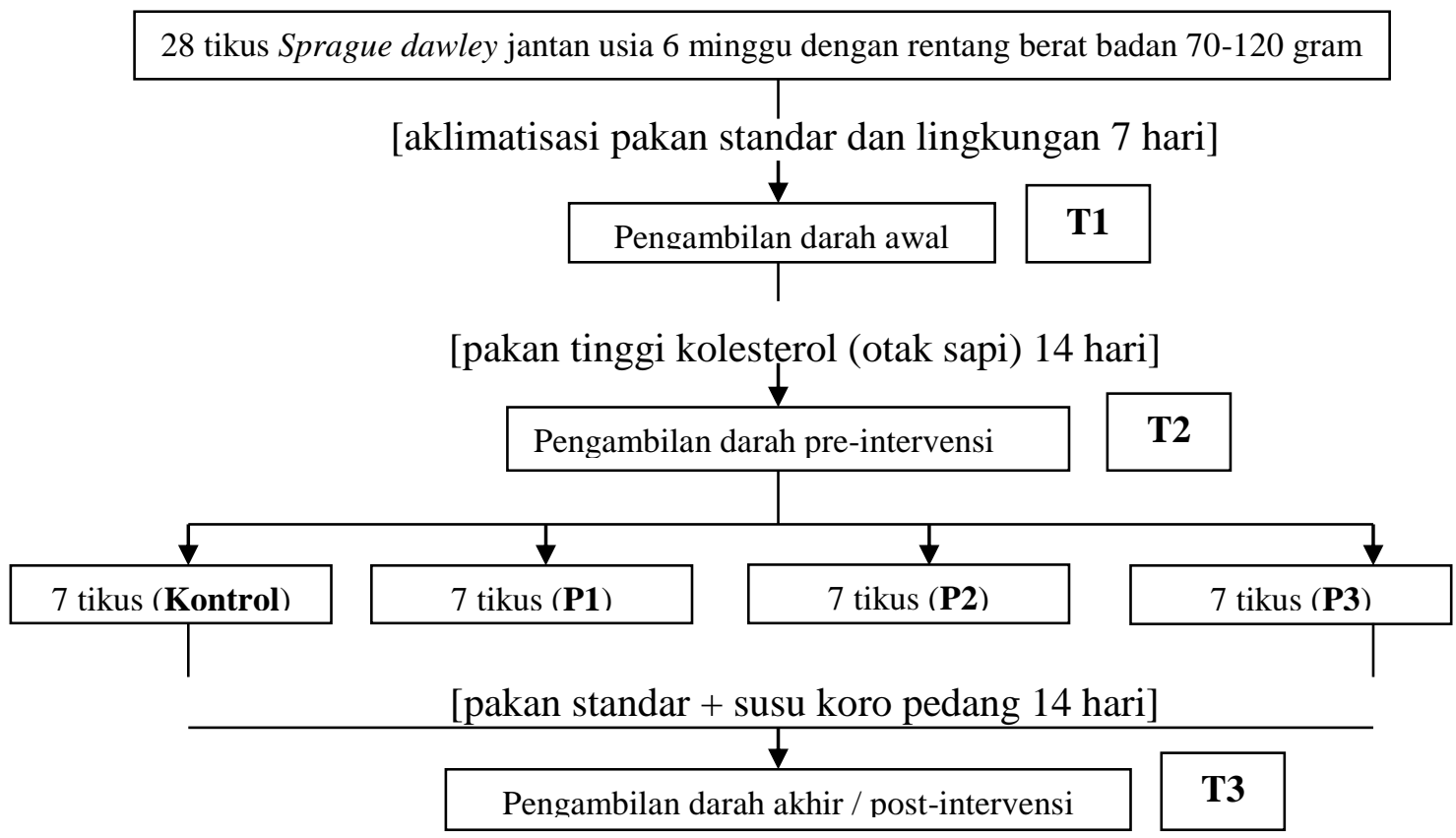

Gambar 1. Bagan Alur Kerja Penelitian

Seluruh subjek penelitian dipelihara di kandang individual dan diberi pakan standar sebanyak 20-40 g serta aquades. Masing-masing subjek sudah dikelompokkan sebelum aklimatisasi. Aklimatisasi dilakukan selama 7 hari. Di akhir tahapan aklimatisasi dilakukan pengambilan darah untuk mengetahui kadar kolesterol total dan trigliserida awal. Selanjutnya subjek diberikan pakan tinggi kolesterol berupa otak sapi kukus yang dihaluskan dengan aquades menggunakan perbandingan 2:1 yang diberikan sebanyak 3 $\mathrm{ml} / \mathrm{ekor}$ /hari selama 14 hari melalui sonde. Pengambilan darah kedua dilakukan pada hari ke15 untuk mengetahui kadar kolesterol total dan trigliserida pre-intervensi. Setelah itu, subjek diberikan susu koro pedang selama 14 hari melalui sonde. Di hari ke-30 dilakukan pengambilan darah akhir untuk mengetahui kadar kolesterol total dan trigliserida post-intervensi. Sebelum pengambilan darah, semua subjek dipuasakan selama 12 jam.

Susu koro pedang dibuat menggunakan metode Cornell termodifikasi. Urutan cara pembuatan susu adalah sebagai berikut : penyortiran, blanching pada suhu $75-95^{\circ} \mathrm{C}$ selama 10 menit, perendaman kacang dalam larutan $\mathrm{NaCl}$ 5\% dengan perbandingan 1:10 selama 24 jam (penggantian air setiap $12 \mathrm{jam}$ ), pengupasan, pencucian dengan air bersih sebanyak 2 kali, perebusan selama 60 menit, perendaman selama 60 menit, pengukusan selama 30 menit, penggilingan kacang dengan air (perbandingan $2: 1$ ), penyaringan ampas susu, dan penguapan dengan suhu $<60^{\circ} \mathrm{C}$ sampai volume susu menjadi 3 $\mathrm{ml}^{4,14,15}$

Pengambilan darah tikus dilakukan melalui plexus retro orbitalis sebanyak $\pm 2.5 \mathrm{cc}$ dan dimasukkan ke dalam tabung bersih. Selanjutnya darah tikus disentrifuge untuk mendapatkan serumnya. Pengukuran kadar kolesterol total dan trigliserida ditentukan menggunakan metode CHOD-PAP dan GPO-PAP di Balai Laboratorium Kesehatan Provinsi Jawa Tengah.

\section{Analisis Data}

Data kolesterol total dan trigliserida dianalisis secara statistik menggunakan program komputer SPSS 17. Data tersebut diuji normalitasnya menggunakan uji Saphiro-Wilk. Kemudian dilakukan uji beda parametrik paired $t$ test pada kadar kolesterol total dan trigliserida sebelum dan sesudah pemberian pakan tinggi kolesterol serta kadar kolesterol total dan trigliserida sebelum dan sesudah pemberian susu koro pedang pada berbagai kadar pemberian. Perbedaan pengaruh dari keseluruhan perlakuan dianalisis menggunakan uji statistik parametrik One way Anova yang dilanjutkan dengan uji LSD 
(Least Significant Difference) untuk melihat perbedaan pengaruh antar kelompok perlakuan. Semua uji yang dilakukan menggunakan tingkat kepercayaan $95 \%{ }^{16}$

\section{HASIL}

Selama penelitian terdapat 3 tikus drop out, masing-masing sebanyak 1 ekor pada kelompok kontrol, P1, dan P3 sehingga jumlah subjek penelitian pada akhir penelitian berjumlah 25 ekor.
Data yang diolah berasal dari 24 subjek agar memudahkan proses analisis data. Sistem pengambilan 1 subjek dari kelompok P2 dilakukan secara acak.

\section{Perkembangan Berat Badan dan Asupan Pakan} Standar Tikus

Perkembangan berat badan dan asupan pakan standar tikus Sprague dawley selama penelitian dapat dilihat pada Gambar 2 dan 3.

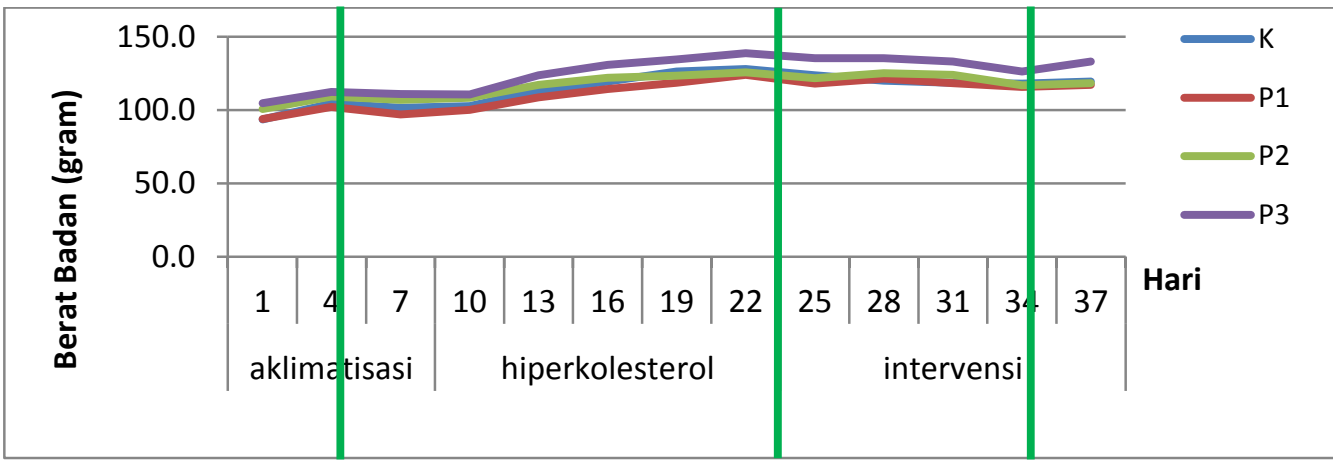

Gambar 2. Perkembangan Berat Badan Tikus Sprague dawley

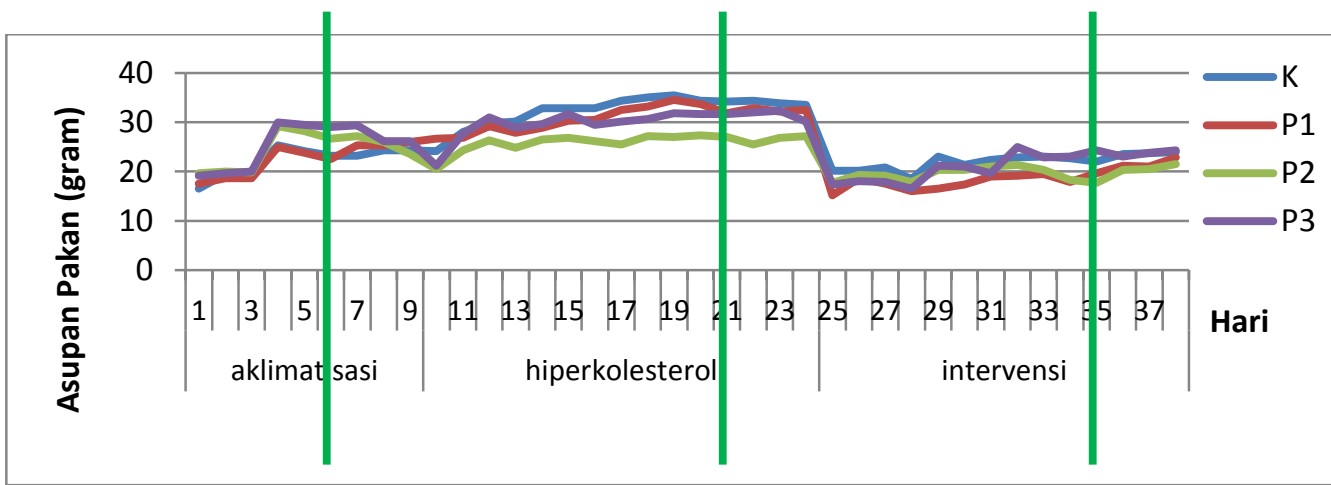

Gambar 3. Perkembangan Asupan Pakan Standar Tikus Sprague dawley

Gambar 2 menunjukkan bahwa selama pemberian pakan tinggi kolesterol, berat badan tikus pada semua kelompok perlakuan mengalami peningkatan. Kenaikan terbesar terjadi pada kelompok P3 (18.3\%). Namun selama pemberian susu koro pedang, perkembangan berat badan tikus cenderung stabil dan hanya mengalami sedikit peningkatan. Hal ini dibuktikan dengan persentase kenaikan berat badan terbesar pada kelompok P1 $(4.3 \%)$.

Gambar 3 menunjukkan bahwa selama pemberian pakan tinggi kolesterol, asupan pakan tikus pada semua kelompok perlakuan mengalami peningkatan. Kelompok kontrol memiliki kenaikan asupan terbesar (48.12\%). Namun, setelah pengambilan darah pre-intervensi, asupan pakan tikus pada semua kelompok perlakuan lebih rendah apabila dibandingkan saat tahap pemberian pakan tinggi kolesterol. Penurunan asupan pakan terkecil terjadi pada kelompok P2 (23.4\%). Stress akibat rasa sakit yang timbul selama dan setelah pengambilan darah merupakan kemungkinan penyebab menurunnya asupan pakan, sehingga mempengaruhi perkembangan berat badan. Akan tetapi, tidak terdapat korelasi yang signifikan antara berat badan dan asupan pakan tikus saat ( $\mathrm{p}$ $>0.05$ )

\section{Kandungan Zat Gizi Kacang dan Susu Koro Pedang}

Berikut adalah kandungan zat gizi kacang koro pedang per $100 \mathrm{~g}$ dan susu dengan kadar koro pedang sebesar $100 \mathrm{~g}$. 
Tabel 1. Kandungan Zat Gizi dengan Pengaruh Hipokolesterolemi dan Asam Sianida (HCN) pada Kacang dan Susu Koro Pedang

\begin{tabular}{lcccc}
\hline \multicolumn{1}{c}{ Zat Gizi } & $\begin{array}{c}\text { Kacang Koro } \\
\text { Pedang 100 g }\end{array}$ & Susu Koro Pedang & Penurunan & $\begin{array}{c}\text { Persen } \\
\text { Penurunan } \\
(\%)\end{array}$ \\
\hline Serat Kasar (g) & 3.73 & 2.17 & 1.56 & 41.82 \\
Isoflavon (g) & 9.81 & 5.9 & 3.91 & 39.86 \\
Saponin (g) & 1.99 & 1.15 & 0.84 & 42.21 \\
Fenol (g) & 15.23 & 9.41 & 5.82 & 38.21 \\
Asam Sianida (ppm) & 5.89 & 2.11 & 3.78 & 64.18 \\
\hline
\end{tabular}

Kadar serat kasar, isoflavon, saponin, dan fenol susu koro pedang mengalami penurunan setelah proses pengolahan. Perendaman, pengupasan, pencucian, dan penguapan merupakan tahap dimana kadar zat gizi tersebut kemungkinan mengalami penurunan. Asam sianida dalam susu koro pedang termasuk dalam kadar yang aman untuk dikonsumsi berdasarkan anjuran dari Food and Drugs Administration (FDA) bahwa standar asam sianida yang tidak bersifat toksik bagi tubuh $<10$ ppm. ${ }^{15,17-19}$

Perubahan Kadar Kolesterol Total dan Trigliserida Sebelum dan Sesudah Pemberian Pakan Tinggi Kolesterol

Data kadar kolesterol total dan trigliserida serum tikus pada akhir tahap aklimatisasi dan hari ke-15 penelitian dapat dilihat pada Tabel 2 dan 3:

Tabel 2. Rata-rata Kadar Kolesterol Total Sebelum dan Sesudah Pemberian Pakan Tinggi Kolesterol

\begin{tabular}{lccccccr}
\hline $\begin{array}{c}\text { Kolesterol } \\
\text { Total }\end{array}$ & $\mathbf{n}$ & $\begin{array}{c}\text { Sebelum } \\
(\mathbf{m g} / \mathbf{d l} \pm \mathbf{S D})\end{array}$ & $\begin{array}{c}\text { Sesudah } \\
(\mathbf{m g} / \mathbf{d l} \pm \mathbf{S D})\end{array}$ & $\mathbf{p}$ & $\begin{array}{c}\text { Peningkatan } \\
(\mathbf{m g} / \mathbf{d l} \pm \mathbf{S D})\end{array}$ & $\begin{array}{c}\text { Persen } \\
\text { Peningkatan } \\
(\mathbf{\%})\end{array}$ & $\begin{array}{c}\mathbf{p} \\
\text { ANOVA }\end{array}$ \\
\hline K & 6 & $62.40 \pm 10.96$ & $90.25 \pm 9.58$ & $.000^{*}$ & $27.85 \pm 6.59$ & 44.63 & .085 \\
P1 & 6 & $57.71 \pm 14.06$ & $86.90 \pm 4.45$ & $.006^{*}$ & $29.19 \pm 15.35$ & 50.58 & \\
P2 & 6 & $70.46 \pm 15.51$ & $88.50 \pm 9.80$ & .061 & $18.05 \pm 18.35$ & 25.62 & \\
P3 & 6 & $83.35 \pm 4.38$ & $94.10 \pm 10.32$ & $.043^{*}$ & $10.75 \pm 9.78$ & 12.90 & \\
\hline
\end{tabular}

Tabel 3. Rata-rata Kadar Trigliserida Sebelum dan Sesudah Pemberian Pakan Tinggi Kolesterol

\begin{tabular}{lccccccr}
\hline Trigliserida & $\mathbf{n}$ & $\begin{array}{c}\text { Sebelum } \\
(\mathbf{m g} / \mathbf{d l} \pm \mathbf{S D})\end{array}$ & $\begin{array}{c}\text { Sesudah } \\
(\mathbf{m g} / \mathbf{d l} \pm \mathbf{S D})\end{array}$ & $\mathbf{p}$ & $\begin{array}{c}\text { Peningkatan } \\
(\mathbf{m g} / \mathbf{d l} \pm \mathbf{S D})\end{array}$ & $\begin{array}{c}\text { Persen } \\
\text { Peningkatan } \\
(\boldsymbol{\%})\end{array}$ & $\begin{array}{c}\text { p } \\
\text { ANOVA }\end{array}$ \\
\hline K & 6 & $53.0 \pm 8.7$ & $114.5 \pm 45.9$ & $.031^{*}$ & $61.2 \pm 50.3$ & 115.5 & .882 \\
P1 & 6 & $68.7 \pm 31.0$ & $130.4 \pm 50.4$ & $.001^{*}$ & $61.8 \pm 21.6$ & 90.0 & \\
P2 & 6 & $62.8 \pm 13.4$ & $109.3 \pm 21.1$ & $.009^{*}$ & $46.5 . \pm 27.4$ & 74.0 & \\
P3 & 6 & $75.0 \pm 27.2$ & $126.3 \pm 32.9$ & .052 & $51.3 \pm 49.6$ & 68.4 & \\
\hline
\end{tabular}

Tabel 2 menunjukkan bahwa pada kelompok kontrol, P1, dan P3 memiliki kenaikan kadar kolesterol total serum yang signifikan. Kenaikan terbesar terjadi pada kelompok P1 $(50.58 \%)$. Sementara tabel 3 menujukkan bahwa pada kelompok kontrol, P1, dan P2 memiliki kenaikan kadar trigliserida yang signifikan. Kenaikan terbesar terjadi pada kelompok kontrol (115.5\%). Berdasarkan hasil uji beda, tidak terdapat perbedaan kadar kolesterol total dan trigliserida serum yang signifikan antar kelompok perlakuan setelah pemberian pakan tinggi kolesterol ( $p$ $>0.05$ ).

Perubahan Kadar Kolesterol Total dan Trigliserida Sebelum dan Sesudah Pemberian Susu Koro Pedang

Data kolesterol total dan trigliserida tikus pada hari ke-15 dan hari ke-30 penelitian dapat dilihat pada Tabel 4 dan 5:

Tabel 4. Rata-rata Kadar Kolesterol Total Sebelum dan Sesudah Pemberian Susu Koro Pedang

\begin{tabular}{|c|c|c|c|c|c|c|c|}
\hline $\begin{array}{c}\text { Kolesterol } \\
\text { Total }\end{array}$ & $\mathbf{n}$ & $\begin{array}{c}\text { Sebelum } \\
(\mathrm{mg} / \mathrm{dl} \pm \mathrm{SD})\end{array}$ & $\begin{array}{c}\text { Sesudah } \\
(\mathbf{m g} / \mathbf{d l} \pm \mathrm{SD})\end{array}$ & $\mathbf{p}$ & $\begin{array}{c}\text { penurunan } \\
(\mathrm{mg} / \mathrm{dl} \pm \mathrm{SD})\end{array}$ & $\begin{array}{c}\text { persen } \\
\text { penurunan } \\
(\%)\end{array}$ & $\underset{\text { ANOVA }}{\mathbf{p}}$ \\
\hline $\mathbf{K}$ & 6 & $90.25 \pm 9.58$ & $96.43 \pm 10.61$ & .249 & $-6.18 \pm 11.62^{b}$ & -6.85 & $.001^{*}$ \\
\hline P1 & 6 & $86.90 \pm 4.45$ & $68.85 \pm 10.45$ & $.008^{*}$ & $18.05 \pm 10.51^{\mathrm{a}}$ & 20.77 & \\
\hline $\mathbf{P 2}$ & 6 & $88.50 \pm 9.80$ & $65.15 \pm 18.68$ & $.027^{*}$ & $23.36 \pm 18.51^{\mathrm{a}}$ & 26.40 & \\
\hline $\mathbf{P 3}$ & 6 & $94.10 \pm 10.32$ & $62.55 \pm 13.48$ & $.004^{*}$ & $31.56 \pm 15.47^{\mathrm{a}}$ & 33.54 & \\
\hline
\end{tabular}

Keterangan : Huruf yang berbeda dibelakang angka menunjukkan adanya perbedaan yang nyata 
Tabel 4 menunjukkan bahwa pemberian susu koro pedang dengan berbagai kadar menyebabkan penurunan yang signifikan pada kadar kolesterol total serum di semua kelompok intervensi (P1, P2, dan P3). Penurunan terbesar ditunjukkan oleh kelompok P3 (susu dengan kadar kacang koro pedang 9 g) sebesar $33.54 \%$. Kelompok kontrol tanpa pemberian susu menunjukkan kenaikan kadar kolesterol total serum yang tidak signifikan (6.85\%). Terdapat perbedaan kadar kolesterol total serum yang signifikan antar kelompok perlakuan setelah pemberian susu koro pedang berbagai kadar $(\mathrm{p}=$ 0.001). Hasil uji beda lanjutan menyebutkan bahwa perbedaan tersebut terjadi antara kelompok kontrol dan kelompok intervensi (P1, P2, dan P3). Tetapi antar kelompok intervensi tidak terdapat tidak berbeda nyata.

Tabel 5. Rata-rata Kadar Trigliserida Sebelum dan Sesudah Pemberian Susu Koro Pedang

\begin{tabular}{lccccccc}
\hline Trigliserida & $\mathbf{n}$ & $\begin{array}{c}\text { Sebelum } \\
(\mathbf{m g} / \mathbf{d l} \pm \mathbf{S D})\end{array}$ & $\begin{array}{c}\text { Sesudah } \\
(\mathbf{m g} / \mathbf{d l} \pm \mathbf{S D})\end{array}$ & $\mathbf{p}$ & $\begin{array}{c}\text { Penurunan } \\
(\mathbf{m g} / \mathbf{d l} \pm \mathbf{S D})\end{array}$ & $\begin{array}{c}\text { Persen } \\
\text { Penurunan } \\
(\boldsymbol{\%})\end{array}$ & $\begin{array}{c}\mathbf{p} \\
\text { ANOVA }\end{array}$ \\
\hline K & 6 & $114.5 \pm 45.9$ & $128.4 \pm 29.4$ & .612 & $-13.9 \pm 63.0^{\mathrm{b}}$ & -12.1 & $.026^{*}$ \\
P1 & 6 & $130.4 \pm 50.4$ & $87.8 \pm 29.6$ & .150 & $42.6 \pm 61.5^{\mathrm{a}}$ & 32.7 & \\
P2 & 6 & $109.3 \pm 21.1$ & $64.6 \pm 31.5$ & $.034^{*}$ & $44.7 \pm 37.8^{\mathrm{a}}$ & 40.9 & \\
P3 & 6 & $126.3 \pm 32.9$ & $77.2 \pm 36.5$ & $.014^{*}$ & $49.2 \pm 32.3^{\mathrm{a}}$ & 39.0 & \\
\hline
\end{tabular}

Keterangan : Huruf yang berbeda dibelakang angka menunjukkan adanya perbedaan yang nyata

Tabel 5 menunjukkan pemberian susu koro pedang dengan berbagai kadar menyebabkan penurunan yang signifikan pada kadar trigliserida serum di kelompok P2 dan P3. Penurunan terbesar ditunjukkan oleh kelompok P2 (susu dengan kadar kacang koro pedang 4.5 g) sebesar $40.9 \%$. Sedangkan kelompok kontrol mengalami kenaikan kadar trigliserida serum meskipun tidak signifikan $(12.1 \%)$. Terdapat perbedaan kadar trigliserida serum yang signifikan antar kelompok perlakuan setelah pemberian susu koro pedang berbagai kadar $(\mathrm{p}=0.026)$. Hasil uji beda lanjutan menyebutkan bahwa perbedaan tersebut terjadi antara kelompok kontrol dan kelompok intervensi (P1, P2, dan P3). Tetapi antar kelompok intervensi tidak berbeda nyata.

Korelasi antara Berat Badan dan Asupan Pakan dengan Kadar Kolesterol Total dan Trigliserida

Asupan pakan dan berat badan berhubungan dengan kadar kolesterol total dan trigliserida serum. Oleh karena itu, dilakukan uji untuk menentukan korelasi antara variabel tersebut. Hasil uji korelasi menunjukkan bahwa asupan pakan dan berat badan tidak berkorelasi nyata terhadap kadar kolesterol total dan trigliserida serum $(\mathrm{p}>0.05)$, baik saat pemberian pakan tinggi kolesterol maupun susu koro pedang berbagai kadar. Sehingga asupan pakan dan berat badan bukan merupakan variabel pengganggu (confounding factor) dalam penelitian ini.

\section{PEMBAHASAN}

Kadar Kolesterol Total dan Trigliserida Sesudah Pemberian Pakan Tinggi Kolesterol
Hasil penelitian menunjukkan kenaikan kadar kolesterol total dan trigliserida serum yang signifikan setelah pemberian pakan tinggi kolesterol selama 14 hari pada hampir semua kelompok perlakuan. Peningkatan kadar kolesterol total pada setiap kelompok perlakuan setelah pemberian otak sapi $\geq 12.9 \%$, sedangkan peningkatan kadar trigliserida pada setiap kelompok perlakuan lebih dari $\geq 68.4 \%$. Peningkatan kadar kolesterol total dan trigliserida telah mencapai kondisi hiperkolesterolemia. Hasil ini konsisten dengan penelitian sebelumnya yang menunjukkan bahwa pemberian otak sapi pada tikus Sprague dawley selama 15 hari meningkatkan kadar kolesterol total dan trigliserida masingmasing sebesar $9.2 \%$ dan $49.58 \%$. 20-21

Pakan tinggi kolesterol yang digunakan adalah otak sapi kukus dengan kandungan kolesterol $3100 \mathrm{mg}$ per $100 \mathrm{~g}$, asam lemak jenuh $2 \%$, dan lemak trans $1 \%$. Asam lemak jenuh utama dalam otak sapi kukus adalah asam palmitat $29 \mathrm{mg}$ dan asam stearat $1305 \mathrm{mg}$ per $100 \mathrm{~g}$ bahan. Pada manusia, NCEP (National Cholesterol Education Program ) menganjurkan mengenai asupan kolesterol $\leq 200 \mathrm{mg} /$ hari. Apabila asupan tersebut dikonversi sesuai asupan untuk tikus, asupan kolesterol yang dianjurkan adalah $\leq 3.6 \mathrm{mg} / \mathrm{hari}$. Otak sapi yang diberikan sebanyak $\pm 1.28 \mathrm{~g}$ per tikus per hari mengandung $39.68 \mathrm{mg}$ kolesterol dengan persentase angka kecukupan kolesterol pada tikus sebesar $1066 \% .^{22-23}$

Mekanisme hiperkolesterolemia dimulai dari asupan lemak jenuh dan kolesterol yang berasal dari otak sapi akan dicerna di dalam usus halus sehingga menghasilkan asam lemak bebas, trigliserida, fosfolipid, dan kolesterol. Selanjutnya 
senyawa-senyawa tersebut diubah menjadi kilomikron setelah diserap oleh usus. Terdapat sisa pemecahan kilomikron berbentuk kolesterol bebas bersama dengan apoprotein membentuk VLDL. Selanjutnya enzim lipoprotein lipase sel endotelial mengubah VLDL menjadi IDL (Intermediate Density Lipoprotein) yang bertahan selama 2-6 jam sebelum berubah menjadi LDL. ${ }^{24}$

Kontrol kadar kolesterol darah bergantung pada pembentukan LDL yang dapat teroksidasi sehingga tidak dapat kembali ke dalam aliran darah. Apabila kadar LDL dalam tubuh berada pada kadar tinggi, kolesterol akan menempel pada dinding pembuluh darah dan menimbulkan plak. Ditambah lagi, asupan kolesterol, lemak jenuh, dan lemak trans akan meningkatkan kadar kolesterol total dan trigliserida dengan cara meningkatkan penimbunan lemak di hepar sehingga jumlah asetil Ko A di dalam sel hepar meningkat dan berbanding lurus dengan peningkatan aktivitas enzim HMG Ko A reduktase. Peningkatan enzim tersebut akan meningkatkan kapasitas produksi kolesterol. ${ }^{24}$

Kadar Kolesterol Total dan Trigliserida Sesudah Pemberian Susu Koro Pedang

Hasil penelitian dari tabel 4 menunjukkan penurunan kadar kolesterol total serum yang signifikan pada semua kelompok intervensi setelah pemberian susu koro pedang berbagai kadar. Sementara kelompok kontrol mengalami kenaikan kadar kolesterol total serum meskipun tidak signifikan. Perubahan kadar trigliserida serum pada tabel 5 menunjukkan bahwa susu koro pedang dengan kadar $2.25 \mathrm{~g}$ di kelompok P1 tidak menyebabkan penurunan kadar trigliserida secara signifikan, sedangkan pada kadar 4.5 dan $9 \mathrm{~g}$ menunjukkan penurunan yang signifikan. Pada kelompok kontrol, kadar trigliserida serum mengalami kenaikan meskipun tidak signifikan. Hasil analisis lanjut pada perubahan kadar kolesterol total dan trigliserida serum menunjukkan terdapat perbedaan yang signifikan antar kelompok kontrol dengan kelompok intervensi (P1, P2, P3).

Penurunan kadar kolesterol total dan trigliserida dipengaruhi oleh kandungan serat, fenol, isoflavon, saponin, dan niasin yang terdapat dalam susu koro pedang. Meskipun belum dilakukan uji terhadap kadar serat pangan kacang dan susu koro pedang, terdapat sebuah penelitian yang menyimpulkan bahwa kadar serat kasar adalah sebesar $20-25 \%$ dari kadar serat pangan. Kadar serat kasar pada susu koro pedang yang dibuat dari $100 \mathrm{~g}$ sebanyak $2.17 \mathrm{~g}$, sehingga diperkirakan mengandung kadar serat pangan sebanyak 6.51-10.85 g. ${ }^{25}$

Mekanisme penurunan kolesterol darah oleh serat adalah dengan meningkatkan ekskresi asam empedu dan kolesterol melalui feses sehingga mengurangi laju siklus enterohepatik empedu dan sintesa kolesterol hepar. Akibatnya penyimpanan kolesterol hepar menurun, sebab kolesterol dialihkan untuk sintesis asam empedu dan kolesterol yang dihantar ke hepar melalui remnant (sisa) kilomikron menjadi lebih sedikit jumlahnya. Penurunan ester kolesterol hepar menyebabkan penurunan pembentukan partikel VLDL. Perubahan simpanan kolesterol hepar berdampak pada aktivitas enzim regulasi metabolisme kolesterol dan jumlah reseptor apoB/E. Jumlah reseptor tersebut bergantung pada katabolisme plasma LDL. Asupan serat yang adekuat meningkatkan jumlah reseptor LDL sebagai respon dari penurunan simpanan kolesterol hepar.. ${ }^{\mathbf{2 6 - 2 7}}$

Mekanisme penurunan kolesterol total dan trigliserida juga disebabkan oleh adanya isoflavon pada kacang koro pedang sebanyak $9.81 \%$. Degradasi kandungan isoflavon bergantung pada waktu dan suhu saat pemasakan (penguapan). Isoflavon dapat menurunkan sintesa trigliserida dan meningkatkan eksresi asam empedu dengan cara meningkatkan aktivitas kolesterol 7 3 hidroksilase. ${ }^{\mathbf{1 9 2 8}}$

Saponin dapat mengikat kolesterol dalam lumen usus, menunda absorbsi lemak dalam usus halus dengan menghambat aktivitas lipase pankreas, mengikat kolesterol dengan asam empedu sehingga sirkulasi enterohepatik asam empedu menurun dan ekskresi kolesterol dalam feses meningkat. Niasin atau yang lebih dikenal sebagai vitamin B3 ditemukan dalam kacang koro pedang segar sebanyak $3.5 \mathrm{mg}$ per $100 \mathrm{~g}$ bahan. Vitamin tersebut digunakan untuk membentuk koenzim Nikotinamid Adenin Dinukleotida (NAD) dan Nikotinamid Adenin Dinukleotida Fosfat (NADP) yang merupakan bentuk aktif dari niasin. Mekanisme penurunan trigliserida oleh niasin adalah dengan menghambat diasilgliserol transferase 2 sehingga sintesis trigliserida terhambat dan menurunkan kadar lipoprotein yang mengandung apolipoprotein-B. Selain itu, niasin dapat menurunkan suplai substrat untuk sintesis VLDL oleh hepar sehingga penurunan produksi VLDL dapat membatasi perubahan trigliserida dari VLDL yang dibantu oleh CETP (cholesteryl ester transfer protein). ${ }^{\mathbf{2 9 - 3 0}}$

$\begin{array}{rrrr} & \text { Homeostasis } & \text { kolesterol dipengaruhi oleh } \\ \text { enzim ACAT } & \text { (Acethyl-Coenzyme } & A\end{array}$

Acetyltransferase). Fenol menurunkan aktivitas 
ACAT yang berfungsi membantu sintesis kolesterol hepatik dari kolesterol dan asetil ko-A. Ester kolesterol disimpan di dalam sel hepar atau dikemas dalam bentuk lipoprotein dan diangkut menuju jaringan lainnya. Aktivitas ACAT yang tingi dipengaruhi oleh simpanan kolesterol hepatik sehingga berpengaruh pada peningkatan sekresi VLDL. Fenol mengurangi sintesis kolesterol dengan menghambat aqualene monooxygenase, enzim yang berperan pada biosintesis kolesterol sehingga kadar kolesterol total dapat ditekan. ${ }^{31}$

\section{SIMPULAN}

1. Pemberian susu koro pedang dengan kadar 2.25 $\mathrm{g}, 4.5 \mathrm{~g}$, dan $9 \mathrm{~g}$ selama 14 hari dapat menurunkan kadar kolesterol total secara signifikan. Penurunan kadar kolesterol total terbesar adalah $33.54 \%$ pada kelompok $\mathrm{P} 3$ yang diberikan susu dari kacang koro pedang $9 \mathrm{~g}$.

2. Pemberian susu koro pedang dengan kadar 4.5 $\mathrm{g}$, dan $9 \mathrm{~g}$ selama 14 hari dapat menurunkan kadar trigliserida secara signifikan. Penurunan kadar trigliserida terbesar adalah $40.9 \%$ pada kelompok P2 yang diberikan susu dari kacang koro pedang $4.45 \mathrm{~g}$.

\section{SARAN}

Pemberian susu koro pedang yang memenuhi standar minimal kandungan asam sianida $(\mathrm{HCN})<10 \mathrm{ppm}$ dapat diujikan pada manusia penderita hiperkolesterolemia karena penelitian terhadap hewan coba memberikan pengaruh yang signifikan terhadap penurunan kadar kolesterol total dan trigliserida.

\section{DAFTAR PUSTAKA}

1. World Health Organization. Raised Cholesterol. 2009 [cited 2014 Apr 11]. Available from http://www.who.int/gho/ncd/risk_factors/cholester ol_text/en.

2. Hatma RD. Lipid Profiles Among Diverse Ethnic Groups in Indonesia. Acta Medica Indonesiana The Indonesian Journal of Internal Medicine. 2011;43(1):4-11.

3. Nimenibo-Uadia R. Effect of Aqueous Extract of Canavalia ensiformis Seeds on Hyperlipidaemia and Hyperketonaemia in Alloxan-induced Diabetic Rats. Biokemistri: Journal of Nigeria Society for Experimental Biology. 2003;15(1):7-15.

4. Wahjuningsih SB, Saddewisasi W. Pemanfaatan Koro Pedang pada Aplikasi Produk Pangan dan Analisis Ekonominya. Riptek. 2013;7(2):1-10.

5. Fitriasari RM. Kajian Penggunaan Tempe Koro Benguk (Mucuna pruriens) dan Tempe Koro Pedang (Canavalia ensiformis) dengan Perlakuan Variasi Pengecilan Ukuran (Pengirisan dan Penggilingan) terhadap Karakteristik Kimia dan
Sensoris Nugget Tempe Koro [skripsi]. Surakarta: Universitas Sebelas Maret. 2010.

6. Istiani Y. Karakterisasi Senyawa Bioaktif Isoflavon dan Uji Aktivitas dari Ekstak Etanol Tempe Berbahan Baku Koro Pedang (Canavalia ensiformis) [tesis]. Surakarta: Universitas Sebelas Maret. 2010

7. Doss A, Pugalenthi M, Vadivel VG, Subhashini G, Anita Subash R. Effects of Processing Technique on The Nutritional Composition and Antinutrients Content of Under-utilized Food Legume Canavalia ensiformis L.DC. International Food Research Journal. 2011;18(3):965-970.

8. Sundaram U, Marimuthu M, Anupama V, Gurumoorthi P. Comparative Antioxidant Quality Evaluation of Underutilized/Less Common South Indian Legumes. International Journal of Pharma and Bio Sciences. 2013; 4(2):117-126.

9. Byun JS, Han YS, Lee SS. The Effects of Yellow Soybean, Black Soybean, and Sword Bean on Lipid Levels and Oxidative Stress in Ovariectomized Rats. International Journal for Vitamin and Nutrition Research. 2010;80(2):97106.

10. Nurcahyaningtyas HR. Efek Antihiperlipidemia Susu Kacang Kedelai (Glycine max (L.) Merr.) pada Tikus Putih Jantan yang Diberi Diit Tinggi Kolesterol dan Lemak [skripsi]. Depok: Universitas Indonesia. 2012.

11. Doucet C, Flament C, Sautier C, Lemonnier D. Effect of an Hypercholesterolemic Diet on The Level of Several Serum Lipids and Apolipoproteins in Nine Rat Strains. Journal of Animal Research and Animal Science (Formerly: Reproduction Nutrition Development). 1987;27(5):897-906.

12. Kučera $\mathrm{O}$, Garnol T, Lotková $H$, Staňková $\mathrm{Y}$, Mazurová Y, Hroch M, et al. The Effect of Rat Strain, Diet Composition and Feeding Period on The Development of a Nutritional Model of NonAlcoholic Fatty Liver Disease in Rats. Journal of Physiological Research. 2011;60:317-328.

13. Sastroasmoro S, Ismael S. Dasar-dasar Metodologi Penelitian Klinis. Bagian Ilmu Kesehatan Anak Fakultas Kedokteran Universitas Indonesia, Jakarta. 2008: p.108-125.

14. Ounorah CE, Adejare AO, Uhiara NS. Comparative Physicochemical Evaluation of Soymilk and Soya Cake Produced by Three Different Methods. Nigerian Food Jounal. 2007;25:28-38

15. Yaqin N. Kajian Penggunaan Tepung Koro Pedang (Canavalia ensiformis) Pada Pembuatan Brownies Kukus [skripsi]. Semarang: Universitas Semarang. 2013.

16. Dahlan MS. Statistik untuk Kedokteran dan Kesehatan. Edisi 3. Jakarta: Salemba Medica. 2001. 
17. Kutoš T, Golob T, Kač M, Plestenjak A. Dietary Fibre Content of Dry and Processed Beans. Food Chemistry. 2003;80:231-5.

18. Góes-Favoni SP, Carrão-Panizzi MC, Beleia A. Changes of Isoflavone in Soybean Cotyledons Soaked in Different Volumes of Water. Food Chemistry. 2010;119:1605-12.

19. Goyal SS, Barwal S. Domestic Processing Effects on Physicochemical, Nutritional, and AntiNutritional Attributes in Soybean (Glycine max L. Merill). International Food Research Journal. 2013;20(6):3203-9.

20. Wahdania F. Pengaruh Pemberian Kefir Susu Sapi terhadap Kolesterol Total Tikus Jantan Sprague dawley [skripsi]. Semarang: Universitas Diponegoro. 2012.

21. Putrisari FN. Pengaruh Pemberian Kefir Susu Sapi terhadap Trigliserida Tikus Jantan Sprague dawley [skripsi]. Semarang: Universitas Diponegoro. 2012.

22. Condé Nast. Nutrition Facts: Beef, variety meats and by-products, brain, cooked, simmered. [cited 2014 June 16]. Available from URL: http://nutritiondata.self.com/facts/beefproducts $/ 3463 / 2$.

23. Nelms M, Sucher KP, Lacey K, Roth SL. Nutrition Therapy and Pathophysiology. 2nd ed. Belmont: Wadsworth Cencage Learning; 2010. p.313

24. Brata HW. Hubungan Pola Makan, Obesitas, Keteraturan Berolahraga dan Kebiasaan Merokok dengan kejadian Hiperkolesterolemia [skripsi]. Semarang: Universitas Muhammadiyah Semarang. 2009.

25. Marlett JA, Bokram RL. Relationship between Calculated Dietary and Crude Fiber Intakes of 200 College Students. American Journal of Clinical Nutrition. 1981;34:335-342.

26. Galisteo M, Duarte J, Zarzuelo A. Effect of dietary fibers on disturbances clustered in the metabolic syndrome. Journal of Nutritional Biochemistry. 2008; 19:71-84

27. Vergara-Jimenez M, Conde K, Erickson SK, Fernandez ML. Hypolipidemic Mechanisms of Pectin and Psyllium in Guinea Pigs Fed High Fatsucrose Diets: Alterations in Hepatic Cholesterol Metabolism. Journal of Lipid Research. 1998;39:1455-1465.

28. Wang Y, Jones P, Ausman L, Lichtenstein A. Soy protein reduces triglyceride levels and triglyceride fatty acid fractional synthesis rate in hypercholesterolemic subjects. Journal of Atherosclerosis.2004;173;269-275.

29. Francis G, Kerem Z, Makkar H, Becker K. The Biological Action of Saponins in Animal Systems; A Review. British Journal of Nutrition. 2002;88:587-605.

30. Markel MD. The Resurgence of Niacin: From Nicotinic Acid to Niaspan/Laropiprant. Israel Medical Association Journal. 2011;13:368-374.
31. Lixian Z, Xin L, Zhengyu J. Effect of Resveratrol on Serum and Liver Lipid Profile and Antioxidant Acivity in Hyperlipidemia Rats. Asian-Australia Journal of Animal Science. 2008;21(6):890-5. 